Cite this: RSC Adv., 2019, 9, 14849
Check for updates

\section{Low voltage operation of a silver/silver chloride battery with high desalination capacity in seawater $†$}

\begin{abstract}
Pattarachai Srimuk, iD ab Samantha Husmann (D) a and Volker Presser (D) *ab
Technologies for the effective and energy efficient removal of salt from saline media for advanced water remediation are in high demand. Capacitive deionization using carbon electrodes is limited to highly diluted salt water. Our work demonstrates the high desalination performance of the silver/silver chloride conversion reaction by a chloride ion rocking-chair desalination mechanism. Silver nanoparticles are used as positive electrodes while their chlorination into $\mathrm{AgCl}$ particles produces the negative electrode in such a combination that enables a very low cell voltage of only $\Delta 200 \mathrm{mV}$. We used a chloride-ion desalination cell with two flow channels separated by a polymeric cation exchange membrane. The optimized electrode paring between $\mathrm{Ag}$ and $\mathrm{AgCl}$ achieves a low energy consumption of $2.5 \mathrm{kT}$ per ion when performing treatment with highly saline feed $(600 \mathrm{mM} \mathrm{NaCl})$. The cell affords a stable desalination capacity of $115 \mathrm{mg} \mathrm{g}^{-1}$ at a charge efficiency of $98 \%$. This performance aligns with a charge capacity of $110 \mathrm{~mA} \mathrm{~h} \mathrm{~g}^{-1}$.
\end{abstract}

Received 5th April 2019

Accepted 7th May 2019

DOI: $10.1039 / \mathrm{c} 9 \mathrm{raO} 2570 \mathrm{~g}$

rsc.li/rsc-advances

by anions and cations in equal number at the initial uncharged state. $^{22-24}$ Thus, charge storage is initially accomplished by concurrent electro-adsorption of counter-ions and ejection of co-ions, which have the same charge sign as the carbon pore wall. Consequently, desalination is only accomplished after the population of co-ions has been depleted; this can be achieved at low and ultralow molar strength, like for brackish water with salinity below $50 \mathrm{mM} .^{25,26}$ This limitation still applies to capacitive deionization with nanoporous carbon, but it is increased when using materials capable of other charge storage mechanisms, such as ion insertion (e.g., sodium manganese oxide, ${ }^{27}$ hexacyanoferrates, ${ }^{28}$ or $2 \mathrm{D}$ layered material ${ }^{25,29}$ ) or reconstitution/conversion reactions (e.g., $\mathrm{Ag} / \mathrm{AgCl},{ }^{27,30} \quad \mathrm{Bi} /$ $\left.\mathrm{BiOCl}^{31}\right)$. Such systems can desalinate highly concentrated saline media $(100-900 \mathrm{mM}){ }^{32}$

The first use of the $\mathrm{Ag} / \mathrm{AgCl}$ conversion reaction in the context of capacitive deionization, corresponds to the seminal work of Blair and Murphy in 1960, which is considered as the first report of capacitive deionization. ${ }^{1}$ In this work, Blair and Murphy investigated half-cells of carbon and modified carbons, most notably, some of them paired with a silver mesh electrode that was anodized at $2 \mathrm{~V}$ in concentrated $\mathrm{NaCl}$ aqueous solution. The authors created a hybrid capacitive deionization cell by using a pair of one electrosorptive (capacitive) carbon electrode with one redox-active (faradaic) $\mathrm{Ag} / \mathrm{AgCl}$ electrode.

After the $1960 \mathrm{~s}, \mathrm{Ag} / \mathrm{AgCl}$ resurfaced in the context of electrochemical desalination in the seminal work of Pasta $e t$ al. in $2012 .{ }^{27}$ In their work, Pasta et al. introduced the so-called desalination battery, which is a cell comprised of one electrode capable of selective sodium uptake and another electrode capable of selective chloride uptake. Specifically, the authors

\footnotetext{
${ }^{a}$ Department of Materials Science and Engineering, Saarland University, 66123 Saarbrücken, Germany. E-mail: v.presser@mx.uni-saarland.de

${ }^{b} I N M$ - Leibniz Institute for New Materials, 66123 Saarbrücken, Germany

$\dagger$ Electronic supplementary information (ESI) available: Supporting electron micrographs, ideal crystal structures, supporting XRD, supporting electrochemical data, and supporting desalination performance. See DOI: $10.1039 / \mathrm{c} 9 \mathrm{ra02570g}$
} 
paired a $\mathrm{Na}_{2-x} \mathrm{Mn}_{5} \mathrm{O}_{10}$ (NMO) electrode with an $\mathrm{Ag}$ electrode to demonstrate the ability of such a cell to effectively desalinate saline media even at molarity typically found for seawater. The combination of $\mathrm{Ag} / \mathrm{AgCl}$ and $\mathrm{NMO}$ was further explored by Chen et al. who reported for $15 \mathrm{mM}$ aqueous $\mathrm{NaCl}(890 \mathrm{ppm})$ a desalination performance of $57 \mathrm{mg} \mathrm{g}^{-1}$ after 100 cycles when sweeping the cell voltage from $-1.0 \mathrm{~V}$ to $+1.5 \mathrm{~V}^{33}$

A novel desalination cell concept, the so-called Na-ion desalination (NID), was introduced by Kyle C. Smith in 2016, with later follow-up work by the same group. ${ }^{34,35}$ In its most simplistic form, the NID concept employs two electrodes of the very same material but with different sodiation states. This can be accomplished, for example, by the use of NMO. During charging, one NMO electrode will uptake sodium ions via cation insertion while the other NMO electrode will release sodium from the crystal structure. Feedwater passes by these two electrodes in two flow channels which are separated by an anion exchange membrane. As one channel becomes enriched by sodium deinserted from the NMO, chlorine ions cross the ion exchange membrane into that channel; thereby, the other channel becomes depleted by chlorine and, at the same time, depleted from sodium that is being inserted into NMO. This yields concurrently desalination in one channel and salination in the other flow channel. The NID cell concept can be used also for other materials and material pairings, as also shown by Lee et al. where sodium nickel hexacyanoferrate was paired with sodium iron hexacyanoferrate. ${ }^{36}$ The latter configuration was labeled rocking-chair desalination battery and yielded a desalination capacity of about $60 \mathrm{mg} \mathrm{g}^{-1}$ in $500 \mathrm{mM} \mathrm{NaCl}$ aqueous solution with a cell voltage of $0.8 \mathrm{~V}$. This cell voltage is much lower than what carbon-based CDI devices would employ but still a much higher desalination capacity is obtained.

Whereas the NID cell uses cation-selective electrodes and an anion-exchange membrane, one can invert the concept by employing an anion-selective electrode and a cation-exchange membrane; therefore, we can call the latter in analogy to the NID technology "CID", which stands for Cl-ion desalination. The first CID work predates even the NID work of Smith and Dmello $^{34}$ in 2012, Grygolowicz-Pawlak et al. used a cationselective membrane (sulfonated tetrafluoroethylene based fluoropolymer-copolymer; Nafion) coated around silver to achieve desalination of aqueous $600 \mathrm{mM} \mathrm{NaCl}{ }^{30}$ This work was adopted and modified for the field of microfluidics by Fighera et al. in 2017 when inkjet-printed $\mathrm{Ag} / \mathrm{AgCl}$ was used as a counter electrode and working electrode for chip-scale water desalination (also using Nafion). ${ }^{37}$ While both these works show the desalination effect of the electrochemical operation of silver, their unique designs and reported experimental data do not allow to assess the desalination performance per electrode mass, cycling stability, and basic electrochemical features. The first CID work presented as an inverted NID system was explored in 2019. Arulrajan et al. used nanoporous carbon cloth without modification and after chemical surfacefunctionalization with (3-aminopropyl)triethoxysilane to enable an anion-selective response. ${ }^{38}$ This material pair was employed in a modified NID cell with a cation-selective membrane to achieve a desalination capacity of about $50 \mathrm{mg}$
$\mathrm{NaCl}$ per $1 \mathrm{~g}$ of electrode material $\left(53 \mathrm{mg} \mathrm{g}^{-1}=0.91 \mathrm{mmol} \mathrm{g}^{-1}\right)$ when operated in $20 \mathrm{mM} \mathrm{NaCl}$ at a cell voltage sweeping between $-0.9 \mathrm{~V}$ and $+0.9 \mathrm{~V}$. Using the same operation parameters of $\Delta 1.8 \mathrm{~V}$ per one CID cycle, the use of two non-modified carbon electrodes (i.e., in the absence of enabled chloride sensitivity) yielded already a desalination capacity of $25 \mathrm{mg} \mathrm{g}^{-1}$. The latter value compares to reports on the same carbon in a conventional CDI cell operating at $0.9 \mathrm{~V}$ by division with a factor of 2; the resulting value of $12.5 \mathrm{mg} \mathrm{g}^{-1}$ is very close to $9 \mathrm{mg} \mathrm{g}^{-1}$ reported by Kim et al. at a lower molar strength of $5 \mathrm{mM} \mathrm{NaCl} .^{39}$ This work showed the versatility of the NID concept but was limited to low-molar strength and the use of carbon-based electrodes.

In our work, we employed the CID cell based on $\mathrm{Ag} / \mathrm{AgCl}$ conversion reaction and a polymer-based cation exchange membrane (Fig. 1). This illustrates how promising conversion reactions are for the desalination of seawater or other aqueous/ saline media. We do so by using commercially available silver nanoparticles (AgNP) for one electrode, and $\mathrm{AgCl}$ obtained from electro-chlorination of AgNP as the other electrode. Therefore, the same $\mathrm{Ag} / \mathrm{AgCl}$ conversion reaction, on forward- and backward direction, is the mechanism by which chlorine is removed. The overall desalination is then accomplished by chargebalancing of the aqueous media across a polymer-based cation-exchange membrane (Fig. 1C). Also, the use of $\mathrm{AgCl}$ in aqueous environments is motivated by the very low solubility of only about $13 \mu \mathrm{M}^{40}$ Such trace amounts of dissolved $\mathrm{AgCl}$ have a useful side effect per the antibacterial property of $\mathrm{Ag}^{+}$ions to disinfect potable water. ${ }^{41}$ Here, we demonstrate the electrochemical response of each electrode separately and the use of the $\mathrm{Ag} / \mathrm{AgCl} \mathrm{CID}$ cell for operation in aqueous $600 \mathrm{mM} \mathrm{NaCl}$. This concentration was chosen to illustrate the use of $\mathrm{Ag} / \mathrm{AgCl}$ CID for seawater desalination but for an ideal saline medium which only contains $\mathrm{NaCl}$. The cell delivers a very high desalination capacity of $115 \mathrm{mg} \mathrm{g}^{-1}$, even though a very small cell voltage of just $\Delta 200 \mathrm{mV}$ is used. This also translates to a low energy consumption of $2.5 \mathrm{kT}$ per ion.

\section{Experimental}

\subsection{Material synthesis and electrode preparation}

Silver nanoparticles (AgNPs) ( $<200 \mathrm{~nm}, 99 \%$, Sigma Aldrich) were used as a precursor for the silver chloride synthesis via electro-chlorination. Prior to AgCl synthesis, the AgNP electrodes were prepared by using two different carbon conducive additive: carbon black and multi-wall carbon nanotubes (CNT).

For AgNP electrode preparation, 80 mass $\%$ of the active material (AgNP) was blended with 10 mass\% carbon black (C65, IMERYS) in isopropanol. Then, 10 mass\% of polyvinylidene fluoride (Sigma Aldrich) was added and mixed with a pestle for 5-10 $\mathrm{min}$ in a mortar. $\mathrm{N}$-Methyl-2-pyrrolidone (NMP) was dropwise added into the solid mixture while stirring until the slurry achieved a thick viscosity. The as-obtained slurry was doctor-blade casted on a graphite sheet (SGL carbon) with a wet thickness of $150 \mu \mathrm{m}$ (dry thickness: $c a .100 \mu \mathrm{m}$ ). The coated electrodes were kept in the fume hood for one day and vacuum 


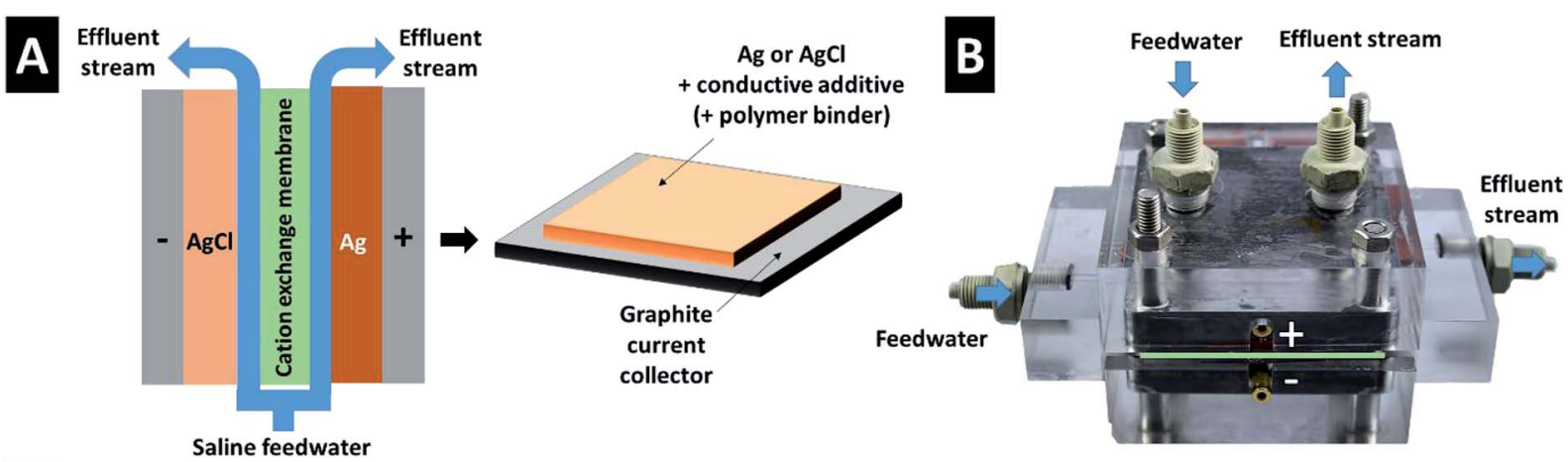

Charging

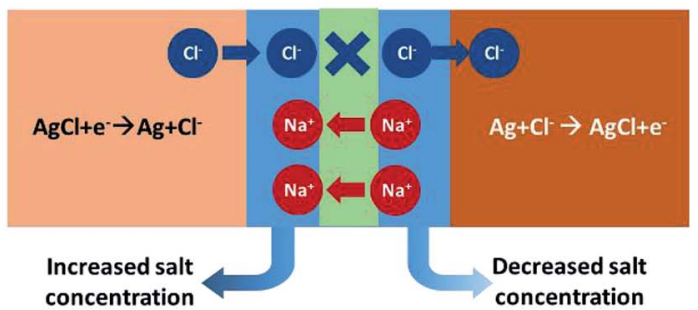

Discharging

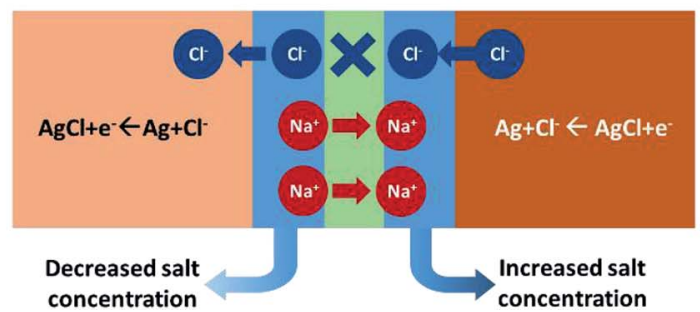

Fig. 1 (A) Scheme of the CID cell and electrode configuration. (B) Photograph of the CID cell. (C) Concept of CID for electrochemical desalination.

dried at $120^{\circ} \mathrm{C}$ for $12 \mathrm{~h}$. This electrode was used directly as it is and was labeled AgNP-10CB.

The $\mathrm{AgCl}$ electrode was derived via electro-chlorination from a binder-free buckypaper electrode composed of AgNP and multi-walled carbon nanotubes. For that, $200 \mathrm{mg}$ of AgNP was mixed with $100 \mathrm{~mL}$ of ethanol and sonicated while stirring for $30 \mathrm{~min}$. At the meantime, $50 \mathrm{mg}$ of carbon nanotubes (CNT, Nanocyl NC7000) was mixed with $100 \mathrm{~mL}$ of ethanol and sonicated while stirring for $30 \mathrm{~min}$ to get a homogeneous suspension. After, the two suspensions were mixed and sonicated for $10 \mathrm{~min}$. Aliquots of $50 \mathrm{~mL}$ of the mixed AgNP and CNT suspension were then vacuum filtered through the polymer membrane (Durapore filter, $220 \mathrm{~nm}$ pore size). After drying at $60{ }^{\circ} \mathrm{C}$ overnight, the free-standing AgNP-CNT electrode was obtained $(100 \mu \mathrm{m}$ thickness $)$ by detaching it from the membrane. The resulting AgNP/CNT electrode had a total content of 20 mass $\%$ of CNT.

For the conversion of the AgNP/CNT into $\mathrm{AgCl} / \mathrm{CNT}$ through an electro-chlorination process, disks with a diameter of $12 \mathrm{~mm}$ were cut from the electrode. The electrode was placed in a custom-built electrochemistry cell using spring-loaded titanium piston; for the setup, refer to ref. 42. To assemble the cell, the AgNP/CNT electrode was used as the working electrode. A $13 \mathrm{~mm}$ diameter of glass fiber mat (GF/A, Whatman) was employed as the separator. An oversized (50 mg) free-standing film of activated carbon (YP-80F, Kuraray; diameter: $12 \mathrm{~mm}$ ) blended with polytetrafluoroethylene (PTFE) with $95: 5$ mass $\%$ (YP-80F/PTFE $95: 5$ ) was used as the counter electrode. $1 \mathrm{M}$ $\mathrm{NaCl}$ was used as the electrolyte and chloride source at the same time. We connected the assembled cell with a VSP300 potentiostat/galvanostat (Bio-Logic) to apply chronoamperometry at $300 \mathrm{mV} v s$. $\mathrm{Ag} / \mathrm{AgCl}$ for $3 \mathrm{~h}$. The cell was disassembled, and the electrode was rinsed with deionized water for several times. The as-obtained chlorinated electrodes were labeled as $\mathrm{Ag} \mathrm{Cl}-20 \mathrm{CNT}$.

\subsection{Structural characterization}

Scanning electron microscopy (SEM) was carried out using a JEOL JSM-7500F system with an acceleration voltage of $3 \mathrm{kV}$. The samples were mounted on carbon sticky tape and analyzed without any conductive sputter coating.

X-ray diffraction (XRD) was conducted with D8 Discover diffractometer (Bruker AXS) with a copper source $\left(\mathrm{Cu}-\mathrm{K}_{\alpha}, 40 \mathrm{kV}\right.$, $40 \mathrm{~mA}$ ), a Göbel mirror, and a $0.5 \mathrm{~mm}$ point focus. A twodimensional VANTEC-500 detector covered an angular range of $20^{\circ} 2 \theta$ with frames recorded at $20^{\circ}, 40^{\circ}$, and $80^{\circ} 2 \theta$ using a measurement time of $1000 \mathrm{~s}$ per frame. Rietveld analysis was carried out with the Bruker AXS software Topas 5.

\subsection{Electrochemical characterization}

Half-cell characterization was carried out with a custom-built cell using spring-loaded titanium pistons..$^{42}$ To assemble the cell, a $12 \mathrm{~mm}$ disk of the electrode material $(2-4 \mathrm{mg})$ was employed as the working electrode. A $13 \mathrm{~mm}$ diameter of glass fiber mat (GF/A, Whatman) was employed as the separator. A free-standing YP-80F/PTFE $95: 5$ electrode (thickness: $600 \mu \mathrm{m}$ ) was used as the counter electrode. The aqueous $\mathrm{NaCl}$ solution was inserted into the cell by vacuum filling with a syringe, and an $\mathrm{Ag} / \mathrm{AgCl}$ reference electrode $(3 \mathrm{M} \mathrm{KCl}, \mathrm{BASi})$ was located at the side of the cell body.

The cell was characterized by using VSP300 potentiostat/ galvanostat (Bio-Logic). For cyclic voltammetry, the cell was cycled between $-0.3 \mathrm{~V}$ and $+0.3 \mathrm{~V} v \mathrm{~s}$. $\mathrm{Ag} / \mathrm{AgCl}$ at the scan rate of $1 \mathrm{mV} \mathrm{s}^{-1}$. For galvanostatic charge/discharge, the specific current of $0.1-10 \mathrm{~A} \mathrm{~g}^{-1}$ was applied to the electrode with the cut- 
off potentials of $-0.3 \mathrm{~V}$ and $+0.3 \mathrm{~V} v s$. Ag/AgCl. The specific capacity of the electrode is calculated according to eqn (1).

$$
Q=\frac{I \times t}{m_{\text {active }}}
$$

where $Q$ is the specific capacity ( $\left.\mathrm{mA} \mathrm{h}^{-1}\right), I$ is the current (mA), $t$ is the time (h), and $m_{\text {active }}(\mathrm{g})$ is the mass of either AgNP or AgCl (i.e., the electrode mass without conductive additive and without polymer binder). To avoid any confusion between specific capacity ( $\left.\mathrm{mA} \mathrm{h} \mathrm{g}^{-1}\right)$ and desalination capacity $\left(\mathrm{mg} \mathrm{g}^{-1}\right)$, we will use the term charge capacity for the specific capacity $\left(\mathrm{mA} \mathrm{h} \mathrm{g}^{-1}\right)$ from here on forth.

\subsection{Desalination performance}

We used an inverted CID cell architecture for electrochemical desalination of aqueous $600 \mathrm{mM} \mathrm{NaCl}$ (Fig. 1A and B). ${ }^{34,38}$ Two flow channel compartments were separated by $180 \mu \mathrm{m}$ thick cation exchange membrane (FKS10, FuMa-Tech). Our cell employed AgNP and $\mathrm{AgCl}$ as the positive and negative electrode, respectively. The cell was connected to the potentiostat/ galvanostat VMP300 (Bio-Logic) using galvanostatic charge/ discharge technique with the cut-off voltage of $\pm 0.1 \mathrm{~V}$ and an applied current of $0.1 \mathrm{~A} \mathrm{~g}^{-1}$. Since the charge capacity of the electrodes does not remain constant, the duration of the desalination operation half-cycles varied from about $300 \mathrm{~s}$ (1st cycle) to about $200 \mathrm{~s}$ (25th cycle). A reservoir of $10 \mathrm{~L}$ of aqueous $600 \mathrm{mM}$ was constantly flushed with $\mathrm{N}_{2}$ gas to remove dissolved $\mathrm{O}_{2}$. All measurements were carried out with a feedwater flow rate of 5 $\mathrm{mL} \min ^{-1}$.

The desalination capacity (DC; $\mathrm{mg} \mathrm{g}^{-1}$ ) was calculated by use of eqn (2).

$$
\mathrm{DC}=\frac{v \times M_{\mathrm{NaCl}}}{m_{\text {active }}} \int c \mathrm{~d} t
$$

where $c$ (in $\mathbf{M}$ ) is the measured molar concentration, $t$ is the time, $\nu$ is the volumetric flow rate $\left(\mathrm{L} \mathrm{s}^{-1}\right), M_{\mathrm{NaCl}}$ is the molar mass of $\mathrm{NaCl}\left(58.440 \mathrm{~g} \mathrm{~mol}^{-1}\right)$, and $m_{\text {active }}(\mathrm{g})$ is the active electrode mass. The concentration of $\mathrm{NaCl}$ was recorded with a Metrohm PT1000 conductometric cell, and the $\mathrm{pH}$ values were recorded with a WTW SensoLyt 900P sensor probe.

The charge efficiency (CE; ref. 10) was calculated by eqn (3):

$$
\mathrm{CE}=\frac{F \times \mathrm{DC}}{36 \times Q \times M_{\mathrm{NaCl}}}
$$

where $F$ is the Faraday constant (96485 $\mathrm{A} \mathrm{s} \mathrm{mol}^{-1}$ ), DC is the $\mathrm{NaCl}$ desalination capacity, $36(=100 / 3600)$ is multiplied to $Q$ for the unit conversion from $\mathrm{mA}$ h to Coulomb, $Q$ is the measured charge, and $M_{\mathrm{Na}}$ is the molecular weight of sodium chloride.

\section{Results and discussion}

\subsection{Structural characterization}

Fig. 2A shows scanning and transmission electron micrographs of AgNP blended with 10 mass\% carbon black (AgNP-10CB). The well-dispersed AgNP agglomerates are composed of individual silver particles of around 50-60 nm. As confirmed by X-ray diffraction (Fig. 1B), the structure of AgNP is highly crystalline and face-centered cubic (space group $F m \overline{3} m$; ESI, Fig. S1 $\dagger$ ) with a lattice constant of $a=4.0897 \AA$ and an average coherence length (domain size) of $75 \mathrm{~nm}$ (ESI, Table S1†). The finite domain size also visibly broadens the diffraction cones, as can be seen in the two-dimensional diffraction pattern (Fig. 2B).

As compared to the initial AgNP, the AgCl-20CNT shows a much coarser domain size with $\mathrm{AgCl}$ grains entwined within the CNT network (Fig. 2C). A domain size of more than $200 \mathrm{~nm}$ and the absence of peak broadening is confirmed by XRD (Fig. 2D). By use of Rietveld refinement, we have determined $85 \%$ conversion of $\mathrm{Ag}$ to $\mathrm{AgCl}$ in the $\mathrm{AgCl}-20 \mathrm{CNT}$ electrodes (ESI, Table S1†). Residual Ag in the AgCl-20CNT electrodes has also lost the nanoscale feature of AgNP and exhibits a lattice spacing of $a=4.0905 \AA$. $\mathrm{AgCl}$ is also cubic and has a unit cell parameter of $a=5.6200 \AA$.

\subsection{Electrochemical characterization}

The characterization of the AgNP and AgCl electrodes in halfcell configuration was performed using aqueous $1 \mathrm{M} \mathrm{NaCl}$ to measure the basic electrochemical behavior and to quantify the charge storage capacity (Fig. 3). The overall reaction of Ag to $\mathrm{AgCl}$ and of $\mathrm{AgCl}$ back to $\mathrm{Ag}$ is well-known and given in eqn (4). Following this reaction, metallic silver converts to isolative silver chloride; therefore, our experiments ensured electrical conductivity by the presence of a conductive additive. In addition, the initially 15 mass\% of $\mathrm{Ag}$ present in the electrochlorinated AgCl-20CNT electrodes may also improve the charge transport process.

$$
\mathrm{Ag}_{\text {(solid) }}+\mathrm{Cl}_{\text {(aqueous) }}{ }^{-} \rightleftharpoons \mathrm{AgCl}_{\text {(solid) }}+\mathrm{e}^{-}
$$

Cyclic voltammograms of AgNP-10CB and AgCl-20CNT halfcells are shown in Fig. 3A. As the AgNP-10CB electrode is scanned towards the positive potential and stopped at the cutoff potential of $0.3 \mathrm{~V}$ vs. $\mathrm{Ag} / \mathrm{AgCl}$, an oxidation peak at $+101 \mathrm{mV} v s$. $\mathrm{Ag} / \mathrm{AgCl}$ is observed, indicating the formation of $\mathrm{AgCl}$. During the backward scan, the reduction process occurs at $-121 \mathrm{mV} v s . \mathrm{Ag} / \mathrm{AgCl}$ indicative of the reversible reaction of AgCl back to Ag. The AgCl-20CNT electrode shows broad peaks during anodic and cathodic sweeping, with oxidation and reduction peaks at +125 and $-129 \mathrm{mV} v$ s. $\mathrm{Ag} / \mathrm{AgCl}$, respectively.

The potential of oxidation and reduction potential characterizing the conversion reaction between $\mathrm{AgCl}$ and $\mathrm{AgNP}$ (eqn (4)) is explained by the Nernst equation (eqn (5) and (6)). Assuming a one electron transfer and high concentration, the formal potential $\left(E_{\mathrm{f}}\right)$ can be shown as the standard potential $\left(E_{0}\right)$ that is between $-10.5 \mathrm{mV}$ and $-10.6 \mathrm{mV} v s$. $\mathrm{Ag} / \mathrm{AgCl}$ (eqn (3)).

$$
E_{\mathrm{f}}=E_{0}+\frac{R T}{F} \ln \left(\frac{1}{a_{\mathrm{Cl}}}\right)
$$

where is $E_{\mathrm{f}}$ is the formal potential, $E_{0}$ is the standard potential $(-10.5 \mathrm{mV}$ vs. $\mathrm{Ag} / \mathrm{AgCl}), R$ is the gas constant $\left(8.314 \mathrm{~J} \mathrm{~mol}^{-1}\right.$ $\left.\mathrm{K}^{-1}\right), T$ is the temperature (293 K), $F$ is the Faraday constant (96 $485 \mathrm{C} \mathrm{mol}^{-1}$ ), and $a_{\mathrm{Cl}}$ is the activity of chloride ion (equals 1 for high concentrations). 

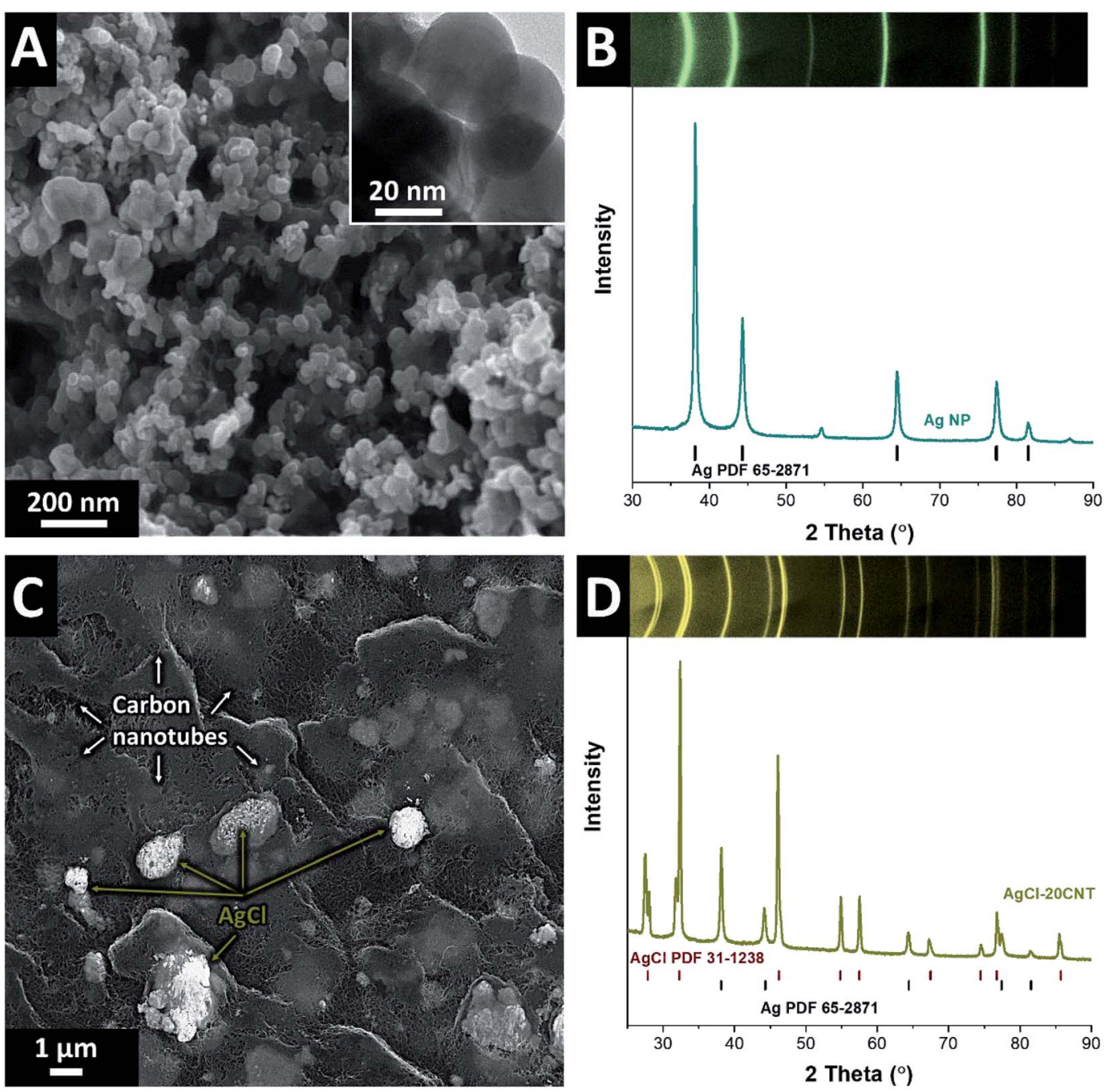

Fig. 2 A) Scanning electron micrograph (inset: transmission electron micrograph) of the AgNP-10CB electrode and (B) X-ray diffraction pattern of the initial AgNP-10CB. (C) Scanning electron micrograph of the AgCl-20CNT electrode and (D) X-ray diffraction pattern of the initial AgCl$20 \mathrm{CNT}$.

$$
E_{\mathrm{e}}=E_{\mathrm{f}}+\frac{R T}{F} \ln \left(\frac{c_{\mathrm{AgCl}}}{c_{\mathrm{Ag}} \times c_{\mathrm{Cl}}}\right)
$$

where $E_{\mathrm{e}}$ is the equilibrium potential, and $c$ gives the concentration of either $\mathrm{AgCl}, \mathrm{Ag}$, or chloride ions.

The galvanostatic charge/discharge profiles (Fig. 3B) of AgNP-10CB and AgCl-20CNT in $1 \mathrm{M} \mathrm{NaCl}$ exhibit clear plateaus at the potential of $\pm 50 \mathrm{mV}$ vs. $\mathrm{Ag} / \mathrm{AgCl}$. This very narrow potential range should benefit desalination operation also within a narrow voltage window for the full-cell operation. The charge capacity of AgNP-10CB is $175 \mathrm{~mA} \mathrm{~h} \mathrm{~g}{ }^{-1}$, which is about $70 \%$ of the maximum theoretical capacity of $\mathrm{Ag}$ being fully converted to $\mathrm{AgCl}$. When cycling AgCl-20CNT, we obtained $140 \mathrm{~mA} \mathrm{~h} \mathrm{~g}^{-1}$ at $0.1 \mathrm{~A} \mathrm{~g}^{-1}$, which equals $77 \%$ of the theoretical maximum.

The overall rate handling of the AgNP-10CB and the AgCl20CNT electrode is relatively high (Fig. 3C). This may be surprising for a conversion-type redox reaction. Of the initial capacity at $0.1 \mathrm{~A} \mathrm{~g}^{-1}, \mathrm{AgNP}-10 \mathrm{CB}$ maintains about $40 \%$ at the very high rate of $10 \mathrm{~A} \mathrm{~g}^{-1}$ (corresponding with a C-rate of about $40 \mathrm{C}$ when considering the theoretical capacity of $\mathrm{Ag}$ ). The $\mathrm{AgCl}-$ 20CNT electrode also maintains about $30 \%$ of the 5 th cycle capacity (and $32 \%$ of the 1 st cycle capacity) at $10 \mathrm{~A} \mathrm{~g}^{-1}$ (corresponding with a C-rate of about $53 \mathrm{C}$ when considering the theoretical capacity of $\mathrm{AgCl}$ ).

As the last step for the basic electrochemical characterization, galvanostatic charge/discharge cycling was performed at a rate of $0.25 \mathrm{~A} \mathrm{~g}^{-1}$ (Fig. 3D). These measurements were carried out after cyclic voltammetry and galvanostatic charge/discharge rate handling; therefore, all electrodes had been cycled several times and, thereby, conditioned. Accordingly, AgCl-20CNT, which initially had shown a slight decrease of the charge capacity (Fig. 3C), provides a stable charge capacity of $100 \mathrm{~mA} \mathrm{~h} \mathrm{~g}{ }^{-1}$ with no significant further decrease over the course of 100 cycles (Fig. 3D). The AgNP-10CB electrodes consistently provide a much higher capacity of $170 \mathrm{~mA} \mathrm{~h} \mathrm{~g}^{-1}$ in the first cycle; this capacity is gradually reduced to reach $137 \mathrm{~mA} \mathrm{~h} \mathrm{~g}{ }^{-1}$ after 100 cycles (loss of 19\%). Yet, the 

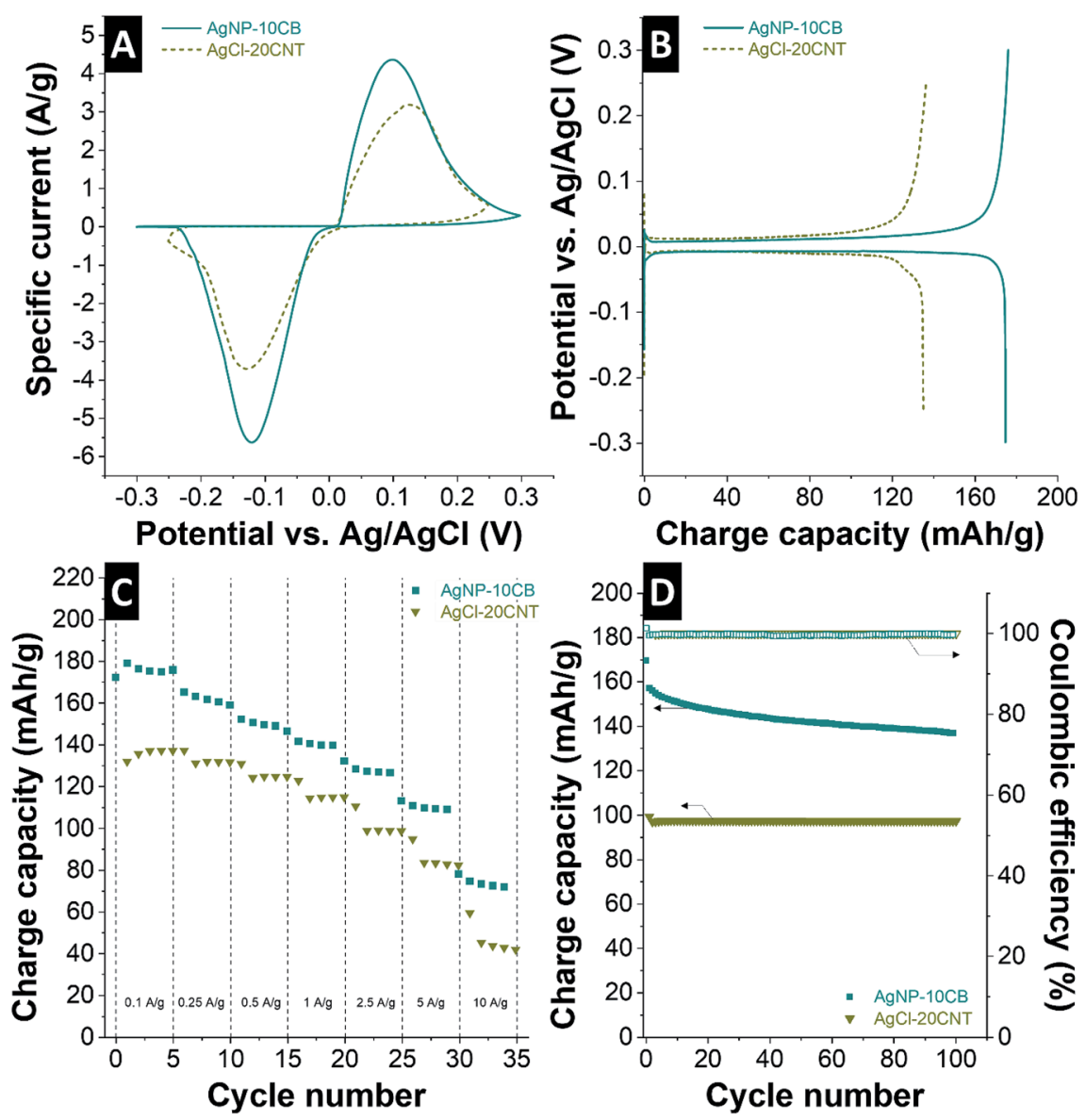

Fig. 3 Electrochemical characterization using a half-cell setup and $1 \mathrm{M} \mathrm{NaCl}$ for AgNP-10CB and AgCl-20CNT electrodes. (A) Cyclic voltammetry at $1 \mathrm{mV} \mathrm{s}^{-1}$, (B) galvanostatic charge/discharge at $0.1 \mathrm{~A} \mathrm{~g}^{-1}$, (C) galvanostatic rate handling at $0.1-10 \mathrm{~A} \mathrm{~g}^{-1}$, and (D) galvanostatic charge/ discharge cycling stability at $0.25 \mathrm{~A} \mathrm{~g}^{-1}$.

performance loss per cycles decreases over time. Post-mortem analysis of the AgNP-10CB electrodes after electrochemical operation in aqueous $1 \mathrm{M} \mathrm{NaCl}$ show that the performance decrease aligns with a potential-induced Ostwald ripening and coarsening of the particle size that leads to incomplete $\mathrm{Ag} / \mathrm{AgCl}$ conversion; the corresponding X-ray diffraction data and electron micrographs are provided in ESI, Fig. S2. $\dagger$

\subsection{Desalination performance}

Using the CID cell concept shown in Fig. 1, an AgNP-10CB and an $\mathrm{AgCl}$-20CNT electrode pair was used for the desalination of aqueous $600 \mathrm{mM} \mathrm{NaCl}$. The cell operation was carried out by cycling between $-0.1 \mathrm{~V}$ and $+0.1 \mathrm{~V}$, to yield a net voltage difference of $\Delta 200 \mathrm{mV}$. We chose this range based on the galvanostatic charge/discharge profiles seen in Fig. 3B. As can be seen, the plateaus for the $\mathrm{Ag} / \mathrm{AgCl}$ conversion reactions are very flat, and material conversion occurs well below $\pm 0.1 \mathrm{~V} v s . \mathrm{Ag} /$ $\mathrm{AgCl}$. The chosen narrow range demonstrates $\mathrm{Ag} / \mathrm{AgCl}$-based CID operation at a very small cell voltage. The AgNP-10CB and AgCl-20CNT electrodes were separated by two flow channels and a polymer-based cation exchange membrane. As AgNP is converted to $\mathrm{AgCl}$, chlorine ions are removed from one flow channel, and charge compensation of the electrolyte is accomplished by transfer of one sodium ion across the ion exchange membrane into the other flow channel (Fig. 1C). The latter is enriched by sodium ions and, at the same time, by chlorine ions which are liberated as $\mathrm{AgCl}$ is being converted to $\mathrm{Ag}$. Once both electrodes are fully converted to $\mathrm{AgCl}$ or $\mathrm{Ag}$, the operation can be inverted; thereby, the flow channel with increased salt concentration becomes the effluent stream of desalinated water and vice versa.

We first measured the electric response of the cell. The characteristic galvanostatic charge/discharge profile for the $1^{\text {st }}$, $10^{\text {th }}$, and $25^{\text {th }}$ operation cycle of the CID cell is shown in Fig. 4A. The initial charge capacity of $205 \mathrm{~mA} \mathrm{~h} \mathrm{~g}^{-1}$ during charging is very close to the measured discharge capacity of $204 \mathrm{~mA} \mathrm{~h} \mathrm{~g}^{-1}$. There are also significant changes in the charge storage capacity of the CID cell over the course of 10 operation cycles (Fig. 4B), but the values stabilize thereafter at a level of $110 \mathrm{~mA} \mathrm{~h} \mathrm{~g}^{-1}$.

By inverting the cell polarity with a constant current of $0.1 \mathrm{~A} \mathrm{~g}^{-1}$, we see a drastic change in the concentration profile of the effluent stream (Fig. 4C). As desalination is accomplished, the concentration profile of $\mathrm{NaCl}$ first decreases before it goes back to the initial value as the electrodes assume their maximum state of charge. Polarity inversion converts AgCl back to $\mathrm{Ag}$ and $\mathrm{Ag}$ back to $\mathrm{AgCl}$; accordingly, we see an increase in the 

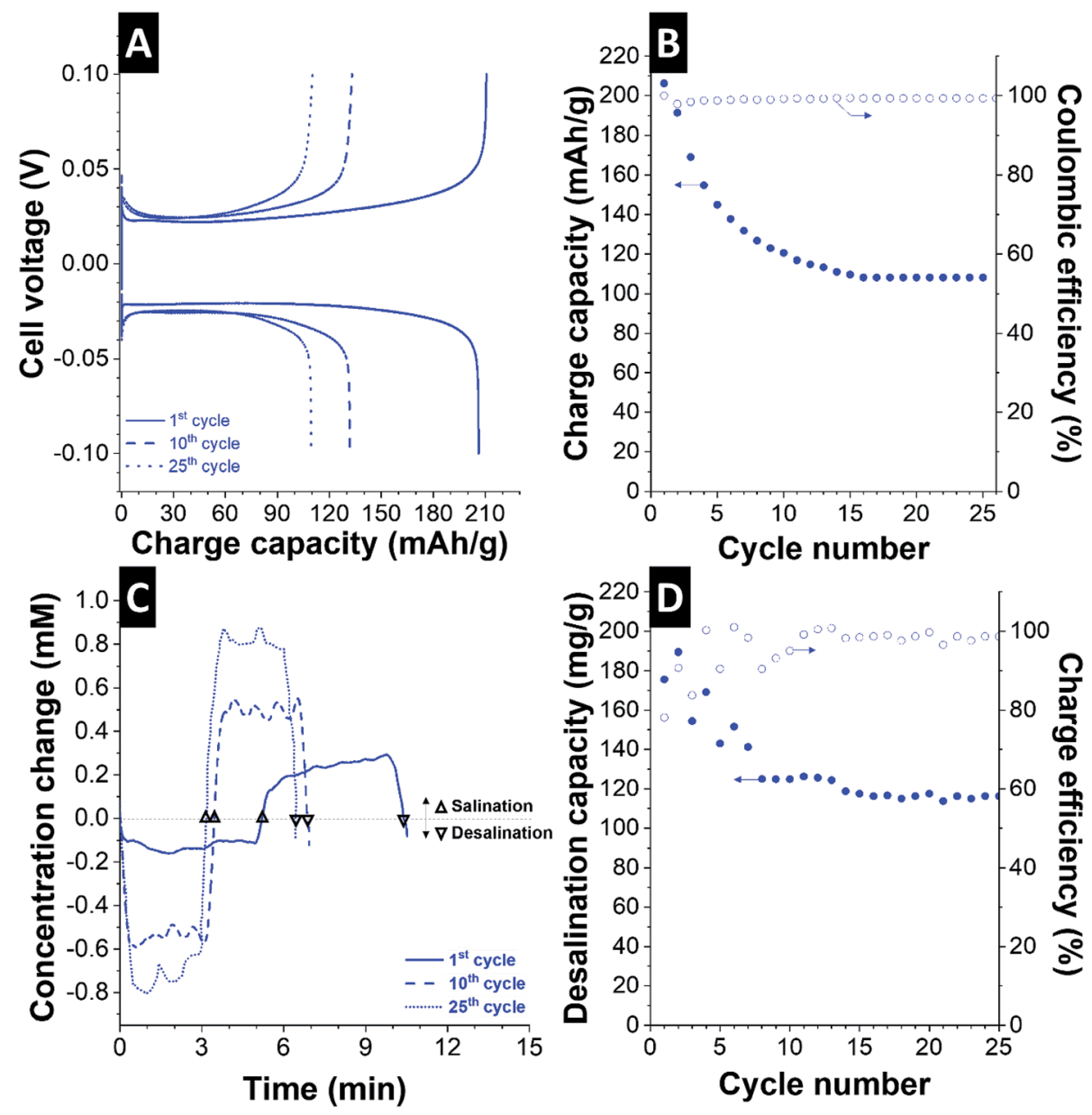

Fig. 4 Electrochemical and desalination performance of AgNP-10CB/AgCl-20CNT CID cell in $600 \mathrm{mM} \mathrm{NaCl} \mathrm{using} \mathrm{a} \mathrm{cell} \mathrm{voltage} \mathrm{of} \Delta 200 \mathrm{mV}$. (A) Charge/discharge profile of the 1st, 10th, and 25th cycle at $0.1 \mathrm{~A} \mathrm{~g}^{-1}$ and (B) corresponding cycling stability of the charge capacity. (C) Concentration change during operation and (D) corresponding desalination capacity and charge efficiency values.

concentration profile. The overall concentration change has an amplitude of about $200 \mu \mathrm{M} \mathrm{NaCl}$ for the first cycle and 600-700 $\mu \mathrm{M} \mathrm{NaCl}$ at the $10^{\text {th }}$ and $25^{\text {th }}$ cycle. This desalination performance is consistent with the small electrode mass of $28 \mathrm{mg}$ that yields the salt removal of $3.22 \mathrm{mg} \mathrm{NaCl}$ (i.e., desalination capacity of $115 \mathrm{mg} \mathrm{g}^{-1}$ ). Hence, about $300 \mathrm{~g}$ of electrode material would be needed to lower the concentration of $600 \mathrm{mM}$ to $10 \mathrm{mM} \mathrm{NaCl}$ for a water volume of $1 \mathrm{~L}$ in just one desalination step (and one $n^{\text {th }}$ of this calculated mass when repeating the process $n$-times).

In alignment with the initial changes in the cell's charge storage performance, there are also changes in the desalination capacity (Fig. 4D). We obtained an initial desalination capacity of $176-190 \mathrm{mg} \mathrm{g}^{-1}$ in $600 \mathrm{mM} \mathrm{NaCl}$. This very high performance correlates with the very high initial charge capacity in excess of $200 \mathrm{~mA} \mathrm{~h} \mathrm{~g}^{-1}$. Like the charge capacity, also the desalination capacity fades after a few cycles; thereby, we measured $125 \mathrm{mg}$ $\mathrm{g}^{-1}$ after 8 cycles, and the performance stabilizes at about $115 \mathrm{mg} \mathrm{g}^{-1}$ after the $15^{\text {th }}$ cycle. This desalination capacity is accomplished at a desalination rate of $23 \mathrm{mg} \mathrm{g}^{-1} \mathrm{~min}^{-1}$ at the applied current of $0.1 \mathrm{~A} \mathrm{~g}^{-1}$. Concurrently, the initially fluctuating charge efficiency stabilized at a level of about $98 \%$ after the $15^{\text {th }}$ cycle. The desalination capacity fading is likely caused by the partially irreversible formation of $\mathrm{AgCl}$ at the positive electrode (AgNP-10CB electrode, Fig. S2 $†$ ). This aligns with the decrease charge capacity half-cell performance during cycling of the AgNP-10CB electrode (Fig. 3D).

Based on the desalination performance, we can quantify the effective energy consumption per cycle. Cycling the AgNP-10CB/ AgCl-20CNT CID cell in $600 \mathrm{mM}$ between $-0.1 \mathrm{~V}$ and $+0.1 \mathrm{~V}$ removes a total of about $115 \mathrm{mg} \mathrm{g}^{-1} \mathrm{NaCl}$ and consumes 97 $\mu \mathrm{W}$ h during charging. This value corresponds with an energy consumption of $2.5 \mathrm{kT}$ per ion in $600 \mathrm{mM} \mathrm{NaCl}$, which can further be reduced when considering recovered energy during discharging of the cell $(92 \mu \mathrm{Wh})$.

\subsection{Charge-vs.-desalination correlation and comparison with other works}

As seen from eqn (2) and (3), there is a universal correlation between the invested electric charge and the number of removed salt ions. The charge-vs.-desalination (CVD) correlation is not losing validity when we compare different desalination cell concepts but is universally applicable (Fig. 5 and ESI, 


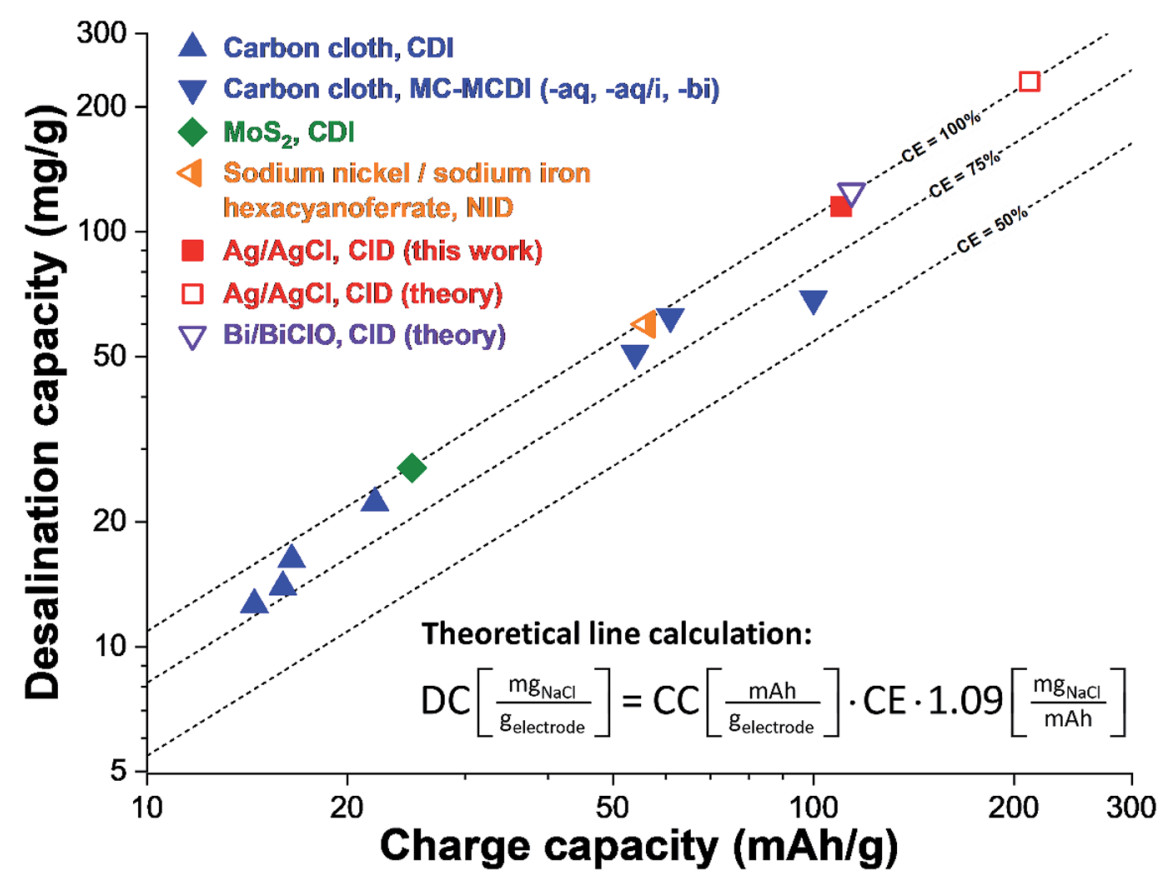

Fig. 5 Charge-vs. - desalination (CVD) plot showing the universal correlation of charge capacity and desalination capacity. The graph shows data for different materials (carbons and non-carbons) and different cell geometries (including CDI, NID, and CID). The theoretical lines assume the stated values for the charge efficiency and are based on eqn (2) and (3). All values are tabulated and with references in ESI, Table S2 $\uparrow$. Cell types: CDI (capacitive deionization), MC-MCDI (multi-channel membrane capacitive deionization), NID (sodium-ion desalination), CID (chlorine-ion desalination). Theoretical line calculation: CE (charge efficiency), CC (charge capacity), DC (desalination capacity).

Table $\mathrm{S} 2 \dagger$ ). In contrast, the desalination capacity value alone may be misleading as the cell and material performance are strongly intertwined. Assuming a charge efficiency of $100 \%$ and ideal ion electrosorption with carbon electrodes, any increase of the cell voltage increases the charge capacity. This can be seen, for example, when we compare the desalination capacity of carbon cloth (Kynol 507-20) operated in a cell cycled between $0 \mathrm{~V}$ and $1.2 \mathrm{~V}\left(\mathrm{DC}=14 \mathrm{mg} \mathrm{g}^{-1}\right)$ with the same material cycles between $+1.2 \mathrm{~V}$ and $-1.2 \mathrm{~V}$ in a CDI cell modified with ion exchange membranes (MCDI; DC $=22 \mathrm{mg} \mathrm{g}^{-1}$ ). ${ }^{9}$ The roughly doubled desalination capacity aligns with an increase in the charge capacity (adjusted for a single electrode) from $16 \mathrm{~mA} \mathrm{~h} \mathrm{~g}{ }^{-1}$ to $22 \mathrm{~mA} \mathrm{~h} \mathrm{~g}^{-1}$ and an increase of the charge efficiency from $79 \%$ to $95 \%$. Even higher charge capacity values are obtained for carbon when using multi-channel MCDI with concentration gradients or organic/aqueous bi-electrolytes system, with maximum values up to $54-61 \mathrm{~mA} \mathrm{~h} \mathrm{~g}^{-1} \cdot \mathbf{9 , 4 3}$

Redox-active electrolytes employing iodide may further enhance the charge storage capacity of carbon electrodes to about $100 \mathrm{~mA} \mathrm{~h} \mathrm{~g}^{-1}$ and the measured desalination capacity of $69 \mathrm{mg} \mathrm{g}^{-1}$ for a cell operated at $0.7 \mathrm{~V}$ aligns with a charge efficiency of $64 \% .^{44}$ This shows that the CVD plot is not limited to technologies based on ion electrosorption but can also be used to map the performance of non-carbon materials. For example, we see for $\mathrm{MoS}_{2}$ a desalination capacity of $27 \mathrm{mg} \mathrm{g}^{-1}$ in aqueous $600 \mathrm{mM} \mathrm{NaCl}$ which aligns with a charge capacity of $25 \mathrm{~mA} \mathrm{~h} \mathrm{~g}^{-1} \cdot{ }^{25}$ The NID cell of Lee et al. employing nickel hexacyanoferrate and sodium iron hexacyanoferrate yielded a desalination capacity of $60 \mathrm{mg} \mathrm{g}^{-1}$ for $500 \mathrm{mM} \mathrm{NaCl}$ per the charge capacity of $56 \mathrm{~mA} \mathrm{~h} \mathrm{~g}^{-1} .^{36}$
From the CVD plot (Fig. 5), we see that the Ag/AgCl desalination performance using cell voltage of just $\Delta 0.2 \mathrm{~V}$ is much higher than using carbon electrodes, even when using cell voltages of $\Delta 2.4 \mathrm{~V}$ or when using multi-channel concentration gradients or redox-active electrolytes. The performance of $115 \mathrm{mg} \mathrm{g}^{-1}$ at $110 \mathrm{~mA} \mathrm{~h} \mathrm{~g}^{-1}$ of our $\mathrm{Ag} / \mathrm{AgCl}$ cell is near the theoretical value of the $\mathrm{Bi} / \mathrm{BiClO}$ conversion reaction operated in a CID cell (125 $\mathrm{mg} \mathrm{g}^{-1}$ at $\left.114 \mathrm{~mA} \mathrm{~h} \mathrm{~g}^{-1}\right)$. Yet, further optimization of the system has great potential for achieving even higher values. When considering the maximum possible charge storage capacity of a well-balanced $\mathrm{Ag} / \mathrm{Ag} \mathrm{Cl}$ system with $100 \%$ charge efficiency and a $100 \%$ degree of reversible conversion, we would expect a desalination capacity of $230 \mathrm{mg} \mathrm{g}^{-1}$ at

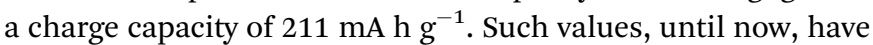
remained elusive for the fast-growing field of electrochemical desalination.

\subsection{Remaining challenges for the Ag/AgCl CID concept}

Our work has shown the very high desalination performance inherent to the $\mathrm{Ag} / \mathrm{AgCl}$ conversion reaction process. Yet, grain coarsening and loss of charge capacity caused a corresponding drop of the desalination capacity. The latter stabilized at $115 \mathrm{mg}$ $\mathrm{g}^{-1}$ which is superior to most materials explored for electrochemical desalination so far, especially when we consider the very small voltage window of $\Delta 200 \mathrm{mV}$. However, $115 \mathrm{mg} \mathrm{g}^{-1}$ is only half of the theoretical value, and while it is unreasonable to assume $100 \%$ utilization of an electrochemical conversion process, there remains significant room for improvement. Clearly, the main electrode design goal must be on maximizing 
the amount of $\mathrm{Ag}$ and $\mathrm{AgCl}$ in the respective electrodes and to use as little conductive additive as possible. Homogeneous phase distribution is of high importance, and we provide in ESI $\dagger$ performance data of non-optimized AgNP and $\mathrm{AgCl}$ electrodes. Most specifically, future work will have to address the large loss of the charge capacity of the $\mathrm{AgCl}$ electrode and the significant particle coarsening.

\section{Conclusions}

Our work has demonstrated the facile use of silver nanoparticles paired with $\mathrm{AgCl}$ as a high-performance desalination battery with two flow-channels separated by a cation-exchange membrane. Such a chloride-ion desalination (CID) cell provides a desalination capacity far beyond the limit of electrosorptive carbon materials per the large charge capacity of the $\mathrm{Ag} / \mathrm{AgCl}$ conversion reaction (theoretical maximum: $211 \mathrm{~mA} \mathrm{~h} \mathrm{~g}^{-1}$ ). When operated in high molarity aqueous solution of $\mathrm{NaCl}$, electrodes based on AgNP yielded a charge capacity of $175 \mathrm{~mA} \mathrm{~h} \mathrm{~g}{ }^{-1}$, while $\mathrm{AgCl}$ electrodes provided $140 \mathrm{~mA} \mathrm{~h} \mathrm{~g}{ }^{-1}$ when operated at $\pm 0.3 \mathrm{~V}$ at a specific current of $0.1 \mathrm{~A} \mathrm{~g}^{-1}$. These values translated in our $\mathrm{Ag} / \mathrm{AgCl}$-based desalination cell even at a very small voltage window of $\pm 0.1 \mathrm{~V}$ (cell voltage of $200 \mathrm{mV}$ ) to a charge capacity of $110 \mathrm{~mA} \mathrm{~h} \mathrm{~g}{ }^{-1}$ and a desalination capacity of $115 \mathrm{mg} \mathrm{g}^{-1}$ at a charge efficiency of about $98 \%$. The low cell voltage of just $\Delta 200 \mathrm{mV}$ allows for very low energy consumption of about $2.5 \mathrm{kT}$ per ion in $600 \mathrm{mM}$ $\mathrm{NaCl}$. Such high desalination capacity at such small voltages and low energy consumption have not been reported in the literature to the best of our knowledge. Yet, the $\mathrm{Ag} / \mathrm{AgCl}$ system may even provide higher desalination performance with further optimization, especially regarding a higher degree of reversible AgCl electrode conversion.

\section{Conflicts of interest}

There are no conflicts to declare.

\section{Acknowledgements}

We thank Eduard Arzt (INM) for his continuing support and Aura Tolosa (INM) for helpful discussions. We acknowledge support by the Deutsche Forschungsgemeinschaft (DFG, German Research Foundation) and Saarland University within the funding program Open Access Publishing.

\section{References}

1 J. W. Blair and G. W. Murphy, in Saline Water Conversion, American Chemical Society, 1960, ch. 20, vol. 27, pp. 206223.

2 S. Porada, R. Zhao, A. van der Wal, V. Presser and P. M. Biesheuvel, Prog. Mater. Sci., 2013, 58, 1388-1442.

3 M. E. Suss, S. Porada, X. Sun, P. M. Biesheuvel, J. Yoon and V. Presser, Energy Environ. Sci., 2015, 8, 2296-2319.

4 M. Noked, A. Soffer and D. Aurbach, J. Solid State Electrochem., 2011, 15, 1563-1578.
5 P. M. Biesheuvel and A. van der Wal, J. Membr. Sci., 2010, 346, 256-262.

6 S. I. Jeon, H. R. Park, J. G. Yeo, S. Yang, C. H. Cho, M. H. Han and D. K. Kim, Energy Environ. Sci., 2013, 6, 1471-1475.

7 Y. Gendel, A. K. E. Rommerskirchen, O. David and M. Wessling, Electrochem. Commun., 2014, 46, 152-156.

8 S. Porada, D. Weingarth, H. V. M. Hamelers, M. Bryjak, V. Presser and P. M. Biesheuvel, J. Mater. Chem. A, 2014, 2, 9313-9321.

9 C. Kim, J. Lee, P. Srimuk, M. Aslan and V. Presser, ChemSusChem, 2017, 10, 4914-4920.

10 R. Zhao, P. M. Biesheuvel, H. Miedema, H. Bruning and A. van der Wal, J. Phys. Chem. Lett., 2009, 1, 205-210.

11 A. Kalfa, I. Cohen, E. Avraham and D. Aurbach, J. Electrochem. Soc., 2019, 166, H119-H125.

12 X. Xu, L. Pan, Y. Liu, T. Lu, Z. Sun and D. H. C. Chua, Sci. Rep., 2015, 5, 8458.

13 X. Xu, Z. Sun, D. H. C. Chua and L. Pan, Sci. Rep., 2015, 5, 11225.

14 S. Porada, L. Borchardt, M. Oschatz, M. Bryjak, J. S. Atchison, K. J. Keesman, S. Kaskel, P. M. Biesheuvel and V. Presser, Energy Environ. Sci., 2013, 6, 3700-3712.

15 C. Zhang, X. Wang, H. Wang, X. Wu and J. Shen, Desalination, 2019, 458, 45-53.

16 S. Hand, X. Shang, J. S. Guest, K. C. Smith and R. D. Cusick, Environ. Sci. Technol., 2019, 53, 3748-3756.

17 C. Zhao, G. Liu, N. Sun, X. Zhang, G. Wang, Y. Zhang, H. Zhang and H. Zhao, Chem. Eng. J., 2018, 334, 1270-1280.

18 S. Porada, F. Schipper, M. Aslan, M. Antonietti, V. Presser and T.-P. Fellinger, ChemSusChem, 2015, 8, 1867-1874.

19 J. Zhang, J. Fang, J. Han, T. Yan, L. Shi and D. Zhang, J. Mater. Chem. A, 2018, 6, 15245-15252.

20 J. Han, L. Shi, T. Yan, J. Zhang and D. Zhang, Environ. Sci. Nano, 2018, 5, 2337-2345.

21 T. Yan, J. Liu, H. Lei, L. Shi, Z. An, H. S. Park and D. Zhang, Environ. Sci. Nano, 2018, 5, 2722-2730.

22 C. Prehal, D. Weingarth, E. Perre, R. T. Lechner, H. Amenitsch, O. Paris and V. Presser, Energy Environ. Sci., 2015, 8, 1725-1735.

23 C. Prehal, C. Koczwara, H. Amenitsch, V. Presser and O. Paris, Nat. Commun., 2018, 9, 4145.

24 C. Prehal, C. Koczwara, N. Jäckel, A. Schreiber, M. Burian, H. Amenitsch, M. A. Hartmann, V. Presser and O. Paris, Nat. Energy, 2017, 2, 16215.

25 P. Srimuk, J. Lee, S. Fleischmann, S. Choudhury, N. Jäckel, M. Zeiger, C. Kim, M. Aslan and V. Presser, J. Mater. Chem. A, 2017, 5, 15640-15649.

26 P. M. Biesheuvel, S. Porada, M. Levi and M. Z. Bazant, J. Solid State Electrochem., 2014, 18, 1365-1376.

27 M. Pasta, C. D. Wessells, Y. Cui and F. La Mantia, Nano Lett., 2012, 12, 839-843.

28 S. Porada, A. Shrivastava, P. Bukowska, P. M. Biesheuvel and K. C. Smith, Electrochim. Acta, 2017, 255, 369-378.

29 P. Srimuk, F. Kaasik, B. Krüner, A. Tolosa, S. Fleischmann, N. Jäckel, M. C. Tekeli, M. Aslan, M. E. Suss and V. Presser, J. Mater. Chem. A, 2016, 4, 18265-18271. 
30 E. Grygolowicz-Pawlak, M. Sohail, M. Pawlak, B. Neel, A. Shvarev, R. de Marco and E. Bakker, Anal. Chem., 2012, 84, 6158-6165.

31 Y. Liu, Z. Jiang, X. Zhang and P. K. Shen, J. Mater. Chem. A, 2018, 6, 20037-20043.

32 M. E. Suss and V. Presser, Joule, 2018, 2, 10-15.

33 F. Chen, Y. Huang, L. Guo, M. Ding and H. Y. Yang, Nanoscale, 2017, 9, 10101-10108.

34 K. C. Smith and R. Dmello, J. Electrochem. Soc., 2016, 163, A530-A539.

35 K. C. Smith, Electrochim. Acta, 2017, 230, 333-341.

36 J. Lee, S. Kim and J. Yoon, ACS Omega, 2017, 2, 1653-1659.

37 M. Fighera, P. D. van der Wal and H. Shea, J. Electrochem. Soc., 2017, 164, H836-H845.
38 A. C. Arulrajan, D. L. Ramasamy, M. Sillanpää, A. van der Wal, P. M. Biesheuvel, S. Porada and J. E. Dykstra, Adv. Mater., 2019, 1, 1806937.

39 C. Kim, P. Srimuk, J. Lee, S. Fleischmann, M. Aslan and V. Presser, Carbon, 2017, 122, 329-335.

40 T. J. Bruno, W. M. Haynes and D. R. Lide, CRC handbook of chemistry and physics: a ready-reference book of chemical and physical data, CRC Press, 2016.

41 L. Fewtrell, Silver: water disinfection and toxicity, Centre for Research into Environment and Health, 2014.

42 D. Weingarth, M. Zeiger, N. Jäckel, M. Aslan, G. Feng and V. Presser, Adv. Energy Mater., 2014, 4, 1400316.

43 C. Kim, P. Srimuk, J. Lee and V. Presser, Desalination, 2018, 443, 56-61.

44 J. Lee, P. Srimuk, S. Carpier, J. Choi, R. L. Zornitta, C. Kim, M. Aslan and V. Presser, ChemSusChem, 2018, 11, 3460-3472. 